\title{
Korean Constitutional Court and Due Process Clause
}

\author{
Jibong Lim*
}

\begin{abstract}
The principle of 'due process' was invented and developed by the countries in Anglo-saxon legal circle. It produced 'procedural justice,' and prevents us from falling into a pitfall that arrogance of the lawyers in Roman Civil law countries could easily fall into thinking 'Justice lies in the codes and lawyers perfectly know about it.' The fact that Korean Constitution in 1987 adopted due process clause implies in a sense that we reflected the dark history of misuse and overuse of law and suppression of human rights in the name of 'law' under military regimes(1962-1987) until then. That is the reason why the due process clause in Korean Constitution is one of the most crucial constitutional provisions in terms of human rights protection whose importance cannot be overemphasized.

First of all, this paper will briefly survey the development of due process principle through the analyses of U.S. Supreme Court's decisions focusing on substantive due process and procedural due process. After that, it will explore the background of the adoption of due process clause in Korean Constitution in 1987 and theories of Korean constitutional law scholars before and after its adoption. In addition, it examines the development of the due process principles in Korea by analyzing the Korean Constitutional Court's decisions. Through these efforts, this paper aims at exploring some issues of consideration for the continuous development of due process principle in Korea in order to make it a kernel provision for 'human rights protection.'
\end{abstract}

* The Author is an Associate Professor of Law, Sogang University College of Law, Korea (email: jibonglim@hotmail.com). He received an LL.B. in 1990 from Seoul National University College of Law; an LL.M. in 1996 and a J.S.D. in 1999 from the University of California at Berkeley School of Law; was a visiting scholar, University of California at Berkeley School of Law (1999-2003); was an Assistant Professor of Law, Konkuk University College of Law, Korea (2000-2006). 


\section{Introduction}

We praise due process of law principle as "the most important constitutional principle for human rights protection." "I) It was not invented by the U.S. but originated from Magna Carta of England in 1215. This legal principle had gradual development in England and was introduced to the U.S. Constitution in $5^{\text {th }}$ and $14^{\text {th }}$ Amendment. In addition, Japanese Constitution also adopted due process clause in Art. $31^{2)}$ after the $2^{\text {nd }}$ World War.

Civil War(1861-1865) in the States was due to the conflicts of interests between the north and the south, and three Post-War Amendments were introduced to the U.S. Constitution in the year of 1865 (13 $3^{\text {th }}$ Amendment $), 1868\left(14^{\text {th }}\right.$ Amendment $)$, and 1970 ( $15^{\text {th }}$ Amendment) just after the Civil War whose common spirit was the prohibition of racial discrimination. Originally, $5^{\text {th }}$ Amendment, added to the U.S. Constitution in 1891, had prescribed that "No person shall ... be deprived of life, liberty or property without due process of law ..." And among the three Post-War Amendments, the Sec. 1 of the $14^{\text {th }}$ Amendments provided, “... nor shall any state deprive any person of life, liberty or property without due process of law." These two clauses are called due process clause in the U.S. Constitution. The due process principle has been developed mainly by the various interpretations of the due process clause by the U.S. Supreme Court. The due process clause has been used frequently by the U.S. Supreme Court in reviewing the constitutionality of a statute or actions of state and federal governments.

This study will briefly survey the development of due process principle through the analyses of Supreme Court's decisions focusing on substantive due process and procedural due process. After that, it will delve into the background of the adoption of due process clause in Korean Constitution in 1987 and the development of the due process principles in Korea by analyzing the Korean Constitutional Court's decisions. In the end, this study aims at exploring some issues of consideration for the continuous development of due process principle in Korea.

1) Young Hu, Korean Constitutional Law [hangukheonbeopron] 349 (Seoul, Pak-young Sa 1990)

2) Art. 31 of Japanese Constitution provides, "No one shall be deprived of life and liberty, or punished with other penalties without due process of law." 


\section{The Development of Due Process Principle in the United States}

\section{1. $14^{\text {th }}$ Amendment as an Incorporation Clause}

The original U.S. Constitution in 1878 had no provisions on constitutional rights. Hence, ten articles of amendments including the $5^{\text {th }}$ Amendment were added to the U.S. Constitution at once and we call these ten articles as 'Bill of Rights.' However, these ten articles could not be applied to the state government but only to the federal government because the articles prescribed "person" as a subject of the rights but did not designate to whom the rights could be asserted.

The $14^{\text {th }}$ Amendment, added to U.S. Constitution in 1868, solved this problem; the state became the object to whom the rights could be asserted by prescribing that no state can deprive life, liberty and property without due process of law. And by incorporating the constitutional rights in Bill of Rights into the term, "liberty," in the $14^{\text {th }}$ Amendment, all the constitutional rights in Bill of Rights came to be asserted to the state government as well as federal government. In this sense, the due process clause in the $14^{\text {th }}$ Amendment are called as "Incorporation Clause."

When understanding the due process clause as demanding the state and federal government to behave with 'fundamental fairness,' we could see the demand from the substantive side as well as the procedural side.

\section{The Birth and Development of Substantive Due Process}

The due process from the substantive side means there's something undoable by the state and federal government although the process is fair and the Constitution does not prohibit that. The idea of natural rights built a nest in the due process clause that 'fundamental rights' exist which the state and federal government cannot restrict without the logic of higher justifications. The fatal weakness of substantive due process is its indeterminateness.

3) John E. NowaK \& Ronald D. Rotunda, Constitutional LaW 368-70 (6 $6^{\text {th }}$ ed. Minnesota, West Group 2000). 


\section{1) Regulations on the Economy and Social Welfare}

In the early times, the notion of substantive due process was developed concerned with economic rights. For this reason, the freedom of contract was derived from the substantive due process like in Lochner case ${ }^{4)}$ in 1905. Many of the regulatory laws on the economy and social welfare were declared unconstitutional in that they infringed the freedom of contract from the substantive due process. But, from the mid-1930s, the U.S. Supreme Court started to apply rationality test standard to the regulatory laws on the economy and social welfare, and declared the regulatory laws on the economy and social welfare constitutional if they have rationality in the minimum sense.

\section{2) Non-economic Regulations concerning Fundamental Rights}

When the regulations by the state and federal government restrict fundamental rights in non-economic area, the U.S. Supreme Court adopted strict scrutiny in its constitutionality test. To pass the strict scrutiny test, the aim of the regulation should be 'compelling' and the regulation should be necessary to accomplish the compelling governmental interest. The government has the burden of proof that the regulation is constitutional.

The fundamental rights from the substantive due process has something to do with the right of privacy. The right to use contraceptive measures ${ }^{5)}$ and the right of abortion $^{6}$ belong to this category. The rights in the family life such as the right to live together ${ }^{7)}$ and the right to educate their children ${ }^{8)}$ are usually fundamental rights. And the newly-emerging rights including right to die, ${ }^{9)}$ right to decline unwanted medical procedures and right to read ${ }^{10)}$ belongs to 'fundamental rights' from substantive due process.

\footnotetext{
4) Lochner v. New York 198 U.S. 45 (1905).

5) Planned Parenthood of Southeastern Pennsylvania v. Casey 505 U.S. 833 (1992).

6) Roe v. Wade 410 U.S. 113 (1973).

7) Moore v. East Cleveland 431 U.S. 494 (1977).

8) Pierce v. Society of Sisters 268 U.S. 510 (1925).

9) Cruzan v. Director, Mo. Dept. of Health 497 U.S. 261 (1990).

10) Stanley v. Georgia 394 U.S. 557 (1969).
} 


\section{The Birth and Development of Procedural Due Process}

The procedural due process means the government should behave according to a proper and fair process in depriving any person of life, liberty or property. In other words, the procedural due process focuses on proper and fair process has been supplied before making any disadvantageous decision. The U.S. Supreme Court established the frame of two-step analysis in applying procedural due process. The first step decides whether the concerned interest belongs to "life, liberty or property" in due process clause. If so, the second step focuses on the question of what process is due.

As for the first-step analysis, the U.S. Supreme Court decided physical liberty, right to drive, right of occupation, right to care of his/her baby belong to "liberty" in due process clause, while the interest to maintain good reputation does not. ${ }^{11)}$ As to "property" in due process clause, the Court declared welfare grant-in-aid ${ }^{12)}$ and certain jobs ${ }^{13)}$ as well as conventional property belong to "property."

As for the second-step analysis, in deciding what process is due, the criteria could be different depending on whether it is about judicial process or non-judicial process. When a person is one of the parties in judicial process, various procedural protection devices are prescribed in the Constitution, including right to a hearing, right to call witness, right to counsel right to a fair and objective trial and right to an appeal. At this time, except for the due process clause, additional procedural protection devices are supplied by other constitutional provisions including right to have jury trial, right to confront a witness against him/her and the right to have the Assistance of Counsel for his/her defense. When it comes to non-judicial process, the government does not need to supply the various procedural protection devices as in judicial process. The Court does balancing test when a person insists to have a specific procedural protection such as invoking the right to a hearing. At this stage, the private interest of the person to have the procedural protection and the governmental interest not to have additional burden from such a procedural protection get balanced. ${ }^{14)}$

11) Paul v. Davis 424 U.S. 693 (1976).

12) Goldberg v. Kelly 397 U.S. 254 (1970).

13) Perry v. Sindermann 408 U.S. 593 (1972).

14) For examples of balancing test in non-judicial process, see Goldberg v. Kelly 397 U.S. 254 (1970); Cleveland Board of Ed. v. Loudermill 470 U.S. 532 (1985). 


\section{The Adoption of Due Process Clause in Korean Constitution and the Development of the Principle}

In England, Magna Carta in 1215 provided that no one shall be deprived of life, property and other individual rights not "by the law of the land."15) The power struggle between King and feudal lords made Magna Carta revised more than 30 times for 20 years after its enactment. ${ }^{16)}$ After that, the term, "due process of law," appeared in Magna Carta when "by the law of the land" was replaced with by the "due process of law" in 1355 under the regime of Edward III. The due process clause was located in the general provisions applying to all the restrictions of constitutional rights in England and the United States. However, in Japanese Constitution, it was located in Art. 31, the provision of a specific right - freedom of body. Japanese Constitution prescribes the freedom of body shall not be restricted without going through "the process by law." In this part, the notion of "due" does not appear in the text by prescribing not "due process by law" but "the process by law." However, the majority of the Japanese public law scholars understand this as a comprehensive provision of due process doctrine. Imitating this provisional style of Art. 31 in Japanese Constitution, Korean Constitution revised in 1987 had due process clause in Art. 12 Sec. $1^{17)}$ and Art. 12 Sec. $3^{18)}$ which are on the freedom of body.

\section{The background adopting due process clause in Korean Constitution in 1987}

The Korean people's demand for direct election for Presidency, which had started in full dress since 1983 in opposition to the existing indirect election system marked its climax at June Struggle in 1987, and the then majority party was obliged to surrender to the people's demand by announcing the June 29 Declaration read by

15) Art. 39 of Magna Carta in 1215.

16) Charles A. Miller, The Forest of Due Process of Law, the American Constitutional Tradition, in DUE PROCESS 5-6 (Pennock \& Champman eds., New York University Press).

17) Art. 12. Sec. 1 provides, "All citizens shall enjoy the freedom of body. No person shall be arrested, detained, searched, seized or interrogated unless it is so authorized pursuant to statute. No person shall be punished, subject to preventive restrictions or to forced labor unless it is so authorized by a statute and due process of law."

18) Art.12 Sec.3 prescribes, "For arrest, detention, seizure or search a warrant issued by a judge in due process of law upon request of a prosecutor shall be presented..." 
Tae-woo Roh, by then the presidential candidate of the majority party. Since then, the representatives of the majority and the minority party have drafted and embellished the new Constitutional amendment by mutual consent which revived the direct election system for presidency. ${ }^{19)}$ And, the new amendment was initiated to the Korean Congress on the $18^{\text {th }}$ of September. At that time, the minority party as well as the majority party had conflicting political interests with each other and strong confidence for taking the helm of state affairs. The short negotiating period for several months between the representatives of the majority party and the minority party led to hasty compromises in many important issues of constitutional revision, and, initially, the adoption of the due process clause was one of them. Due to various forms of pressures from many political forces, hasty political compromises were made between the contending parties without having any experts' review from constitutional law scholars.

At that time, the majority party and the minority one were on a vividly different footing on whether the Korean Constitution should have a constitutional provision on the probation prescribed in Society Security Act which was one of the most sensitive issues then. The draft from the minority party prescribed in the Constitution that the probation could be ordered only "by the decision of the court" while the draft from the majority party was fiercely against the text, "by the decision of the court." It was new Article 12 of Korean Constitution, due process clause, that the dramatic compromise at the last moment of the negotiation for the constitutional revision gave birth to. ${ }^{20)}$ Owing to this compromise, the majority party was able to avoid having a constitutional provision which provided that only a court decision could order probation. In the meantime, the minority party could insert due process clause into the Constitution and have the same effect as Korean Constitution has the text, "Probation shall be possible only by the decision of the court," because, in the future, the constitutional interpretation of due process clause and the legislations that give shape to the due process clause would produce the same effect as the minority party wanted. What attracts our attention is the fact that only the probation was a main issue of the party negotiation in the first stage but, in consequence, the due process

19) For the details on the negotiating agendas between the majority and minority party, see CHEOL-Soo KIM, AN InTRODUCTION To KoREAn CONSTITUTION [heonbeophakgaeron] 77-78 (Seoul, Pakyoung Press 2005).

20) For the details on the negotiation process between the contending parties concerning the due process clause, refer to Sang-cheol Kim, Due Process Clause in Art. 12 of Korean Constitution [heomnbeop je 12 jo, jeokbeopjeolchajohang], 146 KoreAn BAR Journal 67-78 (Seoul, Korean Bar Association 1988). 
clause came to be able to apply to the issuance of many kinds of warrant such as arrest warrant, detention warrant, seizure warrant, and search warrant.

Such a rough-and-ready compromise inserted the term, "due process" in the Art. 12 Sec. $1^{21)}$ and Art. 12 Sec. $3^{22)}$ of Korean Constitution. Due to the various kinds of limitations from the fact that it was the outcome of a hasty compromise, the due process clause could not help revealing some loopholes in the text itself. For instance, that Art. 12. Sec. 1 of Korean Constitution made arrest, detention, seizure, search and interrogation possible only by "the statute", while punishment, preventive restriction and forced labor possible by "the statute and due process of law." Korean Constitution seems to distinguish arrest, detention, seizure, search and interrogation from punishment, preventive restriction and forced labor. Art. 12 Sec. 3 provides "a warrant issued by a judge in due process of law" should be presented for arrest, detention, seizure and search, and this provided room to interpret the due process clause not as a prerequisite for arrest, detention, seizure and search but as a narrow requirement for issuing a warrant. In order to prevent the confusion in the application sphere of due process doctrine and make it clear, Art. 12 Sec. 1 should have been prescribed "No person shall be arrested, detained, searched, seized, interrogated, punished, preventively restricted, or forcibly labored without the statute and due process of law."23)

\section{Theories by Korean Scholars on Due Process Clause}

\section{1) Theories of Korean Scholars Before the Adoption of Due Process Clause}

Before the adoption of due process clause in 1987, Art. 11. Sec1 of old Korean Constitution on the freedom of body provided, "No person shall be arrested, detained, searched, seized, interrogated, punished, preventively restricted, or forcibly labored without the statute."

At that time, the majority of the commentators were in the position that the

21) Art. 12. Sec. 1 provides, "All citizens shall enjoy the freedom of body. No person shall be arrested, detained, searched, seized or interrogated unless it is so authorized pursuant to statute. No person shall be punished, subject to preventive restrictions or to forced labor unless it is so authorized by a statute and due process of law."

22) Art. 12. Sec. 3. prescribes, "For arrest, detention, seizure or search a warrant issued by a judge in due process of law upon request of a prosecutor shall be presented..."

23) For the same opinion, see Sang-cheol Kim, supra note 20, at 67. 
phrase, "without the statute" already implied due process doctrine in that the phrase contains the limitation by due process and, for this reason, the due process clause from England and the U.S. had already been adopted in Korean Constitution. ${ }^{24)}$ The position was based on the fact that the phrase, "not by state law," at Magna Carta was much similar to the concerned phrase of Korean Constitution and the phrase in Magna Carta was regarded as a origin of due process clause by the jurists in all over the world.

However, a small number of constitutional law scholars asserted that the phrase in Korean Constitution, "without the statute," could not be regarded as implying due process doctrine considering the tradition of Anglo-saxon legal circle that the phrase in Magna Carta was later substituted by the phrase, "due process of law" as well as the constitutional structures in Roman civil law countries where legalism was selected as a base of formal Rechtsstaat principle. ${ }^{25}$

In my opinion, although the then majority opinion found the constitutional base for due process of law from the phrase, "without the statute," in Art. 11 Sec. 1 of Korean Constitution, the Korean constitutional law scholars did not make progress in full scale on what concrete contents the due process of law doctrine had and on what kinds of restrictions the due process doctrine could make in the restriction of constitutional rights including the freedom of body. The situation was so same in judicial opinions that the courts such as Korean Supreme Court could not apply due process doctrine in a real case as an adjudicative norm.

2) Theories of Korean Scholars in the early times after the adoption of due process clause

Although the majority of constitutional law commentators found out due process doctrine from the constitutional phrase, "without the statute," before the adoption of the due process clause in Korean Constitution, the fact that the due process clause was adopted and expressly guaranteed in Korean Constitution has started to have a

24) Refer to Young-Sung Kwon, Constitutional Law: A Textbook [heonbeophakgaeron], 315 (Seoul, Bobmun Sa 1981); CHEOL-Soo Kim, AN INTROduction to Korean Constitution [heonbeophakgaeron] 142-143 (Seoul, Pakyoung Press 1987); SANG-Bum Han, Korean Constitution [hangukheonbeop] 212 (Seoul, Yemoon Press 1973).

25) For example, Myong-sun Yoon, The doctrine of due process of law [jeokbubjeolcha-ui beopri] in 26-1 KyUNGHEE UnIVERSITY LAW JouRnal 75-76 (Kyunghee University Legal Research Institute 1992). 
substantial meaning in the point that the due process doctrine has begun to have its base in the text of Constitution while it existed only in the interpretations of Constitution in the past.

\section{(1) Confirmative Provision Theory}

Now, the majority opinion before the constitutional adoption of due process clause became the minority one. This minority opinion still asserted that the phrase, "without the statute," did already imply the limitations from due process doctrine. And, after the constitutional adoption of due process clause, it regarded the new due process clause as a kind of confirmative provision that ascertained an undoubted thing in Korean Constitution. ${ }^{26)}$

(2) Bisectional Theory

This theory premises on the fact that Korea belongs to the Roman Civil Law countries and, hence, Korean Constitution is different from that of Anglo-Saxon Law countries in the structures of constitutional law logics. For this reason, this minority position continues that the interpretation and the specific meaning of due process clause should be different from those of England and U.S. even after the constitutional adoption of due process clause. In other words, the phrase, "due process of law" from Art. 12. Sec. 1 of Korean Constitution means the process should be proper and prescribed by law, which fixes just process because Korean Constitution has a separate provision for the principle of "nulla poena nullum crimen sine lege." In the meantime, the phrase, "due process of law" in Art. 12 Sec. 3 of Korean Constitution means that not only the process but also the substance should be provided by law with proper contents. ${ }^{27)}$

(3) Process and Substance based on Proper Law Theory

This theory accepted the due process doctrine in England and the U.S. in the full scale, and interpreted that "due process of law" from Art. 12. Sec. 1 and Sec. 3.

26) Sang-bum Han, The revised constitutional provision on the freedom of body and its problems [gaejeongdoen sinche-ui jayu gyujeong-gwa geu munjejeom] in WeEkLy National ExAm Magazine [wolgan gosi] 125 (Seoul, Wolgan gosi Press, Dec. 1987); Geon Yang, Constitutional Rights in New Korean Constitution [sae heonbeop-ui gibonkweonjohang] in National Exam Magazine [gosigye] 36 (Seoul, Gosigye Press, Nov. 1987).

27) YounG-Sung KwON, supra note 24, at 344. 
requires the contents of the law should be proper not only in the process but also in the substance. This position was based on the fact that due process clause in Korean Constitution requires propriety as well as legality that the legalism in Roman Civil Law countries only requires. This was the majority opinion. ${ }^{28)}$

However, the most of the scholars who supported this theory understood the due process as a narrow principle applying only to the restriction of freedom of body in Art. 12 of Korean Constitution, paying attention to the location of due process clause; it is in Art. 12 on the freedom of body. This theory also covers the position that the constitutional due process clause only applies to the criminal and probation process, generally applies to the process depriving freedom of body, and means just the guarantees of the right to a trial in the administrative and civil procedures. ${ }^{29)}$

\section{The Positions of Korean Constitutional Court and Recent Scholarly Theories}

\section{1) The Position of Korean Constitutional Court concerning Due Process Clause}

Korean Constitutional Court has a similar position to the third theory above by announcing in many decisions, "The due process clause has been accepted as an independent constitutional principle in Korea and its meaning has been extended not only to the formal process but also to the substantial contents that the substance of the law should have legitimacy as well as rationality." ${ }^{30)}$ In other words, the Court adopted the substantive due process as well as the procedural due process.

As for the application scope and application objects, the Court held in many decisions that due process clause applies not only to the restrictions of the freedom of body but also to all the other constitutional rights, ${ }^{31)}$ and that it applies not only to the

28) CHEOL-Soo Kim, supra note 24, at 358; Young Hu, supra note 1 at 354; Myong-sun Yoon, supra note 25, at 80 .

29) For this position, see Sang-Cheol Kim, supra note 20, at 69.

30) Korean Constitutional Court (hereinafter KCC) Dec. 24, 1992, 92 Hun Ga 8. ). For foreign readers' convenience, "Hun Ga [constitutional case in file 'a']" means a case dealing with the constitutionality of a law or a legal provision referred by general courts, and "Hun Ma [constitutional case in file 'e']" and "Hun Ba [constitutional case in file ' $\mathrm{f}$ ']" represents a case of constitutional complaint."

31) For instance, Art. 33 and Art. 34 of Congressman Election Act was declared unconstitutional because it discriminates non-partisan candidate from partisan one by demanding more trust money and this infringes upon the political right of the non-partisan candidate violating due process principle. Decision of Sep. 8, 1989, 88 Hun Ga 1 
criminal process but also to all the other processes including administrative ${ }^{32)}$ and legislative processes. ${ }^{33)}$ Namely, the Court announced that due process doctrine is "one of the most important basic principles"34) in Korean Constitution controlling all kinds of governmental actions.

In the following, we will look over Korean Constitutional Court's decisions on due process of law dividing them in two categories; first, cases declaring unconstitutionality due to the irrationality or illegitimacy of the contents of law which are similar to substantive due process in the U.S., second, cases declaring unconstitutionality due to not having due process which are similar to procedural due process in the United States.

(1) Cases Declaring Unconstitutionality due to the Irrationality or Illegitimacy of the Contents of Law

The decisions by Korean Constitutional Court declaring unconstitutionality due to not the lack of legality of process and substance but the lack of rationality or legitimacy of the contents of law, which prescribed the process and contents of law are similar to the substantive due process in the point that they picked up the propriety - rationality and legitimacy — of law as a basis violating due process of law.

For examples, Art. 221-2 of Korean Criminal Procedure, which provided the participation of the defendant in the pretrial witness examination as being a judge's discretion was declared unconstitutional in that it violated due process as well as the right to a fair trial because the right of attack and defense of the defendant was exceedingly restricted and the rationality and legitimacy of the means to accomplish the aim of the legislation are lacking. ${ }^{35)}$ The judgment by default in Art. 23 of Special Act to Expedite Lawsuit which enabled the court to declare guilty without taking any evidence to the defendant who was absent for the reason that could not be

(Korean Constitutional Court).

32) For instance, Art. 15 of Lawyers Act was declared unconstitutional for violating due process principle which enabled Minister of Justice order the suspension of business until a judicial decision be made when the lawyer became a defendant in a criminal case. Decision of Nov. 19, 1990, 90 Hun Ga 48 (Korean Constitutional Court).

33) Decision of Sep. 8, 1989, 88 Hun Ga 1 (Korean Constitutional Court).

34) Decision of Dec. 26, 94 Hun Ba 1 (Korean Constitutional Court); Decision of Dec. 24, 92 Hun Ga 8 (Korean Constitutional Court).

35) Decision of Dec. 26, 1996. 94 Hun Ba 1 (Korean Constitutional Court). 
defendant's fault was declared unconstitutional because it violated due process of law in an exceedingly improper manner. ${ }^{36)}$ Art. 21-3 of Government-Vested Property Act, which made the sale contract of government-vested property automatically canceled when the sales amount was not fully paid within a certain period of time, was declared unconstitutional because it violated due process without rationality and legitimacy by making canceled even the sales contract where the purchaser did not pay the sales amount on the justifiable ground. ${ }^{37)}$

(2) Cases Declaring Unconstitutionality Due to the Violation of Procedural Due Process

Among the decisions by Korean Constitutional Court, there are many cases which declared violation of due process when prior notice and the evidentiary hearing of the chance of defense were not given before probation, punishment, or forced labor was ordered. For instance, Art. 15 of Lawyers Act provided the Minister of Justice could order the suspension of business until a judicial decision was made when the lawyer became a defendant in a criminal case. The Court declared it unconstitutional in that it violated due process by omitting the chance of evidentiary hearing before the issuance of the order. ${ }^{38)}$ The proviso of Art. 58-2 Sec. 1 in Private School Act prescribed any teacher in private schools should be necessarily removed from office when indicted in criminal lawsuit. The Court declared it unconstitutional for violating due process because the proviso didn't give the chance of evidentiary hearing such as holding an open disciplinary committee where the concerned teacher could make a statement and submit necessary evidence for him/her. ${ }^{39)}$ Art. 7 Sec. 5 of Special Act for the Punishment of Antinational Activists provided the defendant possible to heavy penalty with no chance of defense by appearing in court. It also enabled the court to make a judgment by default even in case that the absence was not the fault of the defendant. The Court declared it unconstitutional because of the violation of due process. ${ }^{40)}$ Art. 215 and Art. 181 of Customs Act provided the confiscated goods shall be reverted to the national treasury when the offender flee or doesn't appear in four months after the confiscation. The Court held the provision is

36) Decision of July 16, 1998, 97 Hun Ba 21 (Korean Constitutional Court).

37) Decision of June 1, 2000, 98 Hun Ga 13 (Korean Constitutional Court).

38) Decision of Nov. 19, 1990, 90 Hun Ga 48 (Korean Constitutional Court).

39) Decision of July 29, 1994, 93 Hun Ga 3 (Korean Constitutional Court).

40) Decision of Jan. 25, 1996, 96 Hun Ga 5 (Korean Constitutional Court). 
against the Constitution by violating due process because it deprives the suspect of his/her property with neither a formal trial nor an evidentiary hearing. ${ }^{41)}$ The Court declared it unconstitutional that the prosecutor called a witness to his office and keep in custody. The Court held this violated due process because only the prosecutor monopolized the contact with the witness by preventing the other party from seeing the witness. In that situation, the defendant couldn't prepare for the defense against attack from the prosecutor because the defendant could not know what the testimony by the witness in custody would be, and could not help exposing himself/herself to the unforeseen attack from the prosecutor. ${ }^{42)}$

\section{2) The Recent Positions of Korean Constitutional Law Scholars}

As for due process doctrine, the majority of Korean constitutional law scholars have supported the position of Korean Constitutional Court since the Court concentratively poured out many decisions on the due process clause. Now, they understand the due process doctrine as requiring that all kinds of governmental actions should have procedural legality and the substantial contents of the law itself should have rationality and legitimacy. When it comes to the application object and application scope of the due process clause, the majority of Korean constitutional law scholars also regards "punished, subject to preventive restriction or to forced labor" of Art. 12 Sec. 1 of Korean Constitution as not being enumerated but being exemplified. Hence, they esteem due process clause as one of the most important basic principles in Korean Constitution which applies to the restrictions of all the constitutional rights and to all the processes of government when a governmental action gives Korean people any form of disadvantage. ${ }^{43)}$

\section{Lessons from the United States}

However, for such an important basic principles of Constitution for human rights, due process of law, Korean academia and practitioners have not advanced a perfect theory with systematic and elaborate logics. Since its adoption in 1987, less than 20

41) Decision of May 29, 1997, 96 Hun Ga 17 (Korean Constitutional Court).

42) Decision of Aug. 30, 2001, 99 Hun Ma 496 (Korean Constitutional Court).

43) For example, see Young-Sung Kwon, supra note 24, at 423-424. 
years has passed and it was such a short time for that. Hence, it is our urgent and crucial task that we examine the concerned theories and judicial precedents in the U.S. where they say due process theories and precedents are developed most, and, then, connect this to the good use of our due process clause. Of course, as Korean Constitution is different from that of the U.S. or England in provisional style, the structure of human rights protection, legal culture and tradition, the meaning and the role of due process clause cannot be exactly the same as those in the two countries. ${ }^{44)}$ In the realm of universality that we commonly share with the two countries, the implications of due process theories and precedents from the U.S. would give us valuable lessons for us to develop our own theories and judicial decisions in Korea.

Due process principle is an abstract and comprehensive principle and its specific application could be and should be different according to a concrete case. Therefore, it has much room for the future development through the accumulation of the concerned judicial decisions and the development of theories. Particularly, I believe our due process principle has more room for the development in the field of procedural due process. We do not apply due process principle differently depending on whether the case is about judicial process or non-judicial one. Besides, we seldom do a balancing test to decide whether to give a chance of evidentiary hearing in nonjudicial process while the U.S. Supreme Court does. If the theories on the balancing test by judiciary are developed in the application of due process principle in nonjudicial process, the due process theories can be more elaborated in Korea with the accumulation of the concerned judicial decisions. For example, depending on the case, not a prior hearing but a post hearing could be enough and even an evidentiary hearing could be omitted for the reason that there are other procedural protection devices.

\section{Some Issues of Consideration for the Continuous Development of Due Process Principle in Korea}

For the continuous development of due process principle in Korea, I believe there are some issues of consideration as below.

First, the substantive due process has been developed in the States as one of due

44) Myung-sun Yoon, supra note 25, at 77. 
process doctrine. Fundamental rights such as the right of privacy which are not enumerated in the U.S. Constitution derive from the substantive due process. In this sense, the due process clause in the U.S. Constitution has been playing an important role as 'a comprehensive and general clause.' I have emphasized in another paper the pursuit of happiness clause in Art. 10 ${ }^{45)}$ of Korean Constitution should be understood neither as a constitutional provision with a specific and concrete right nor a comprehensive and general clause from which various constitutional rights could be derived. I asserted the pursuit of happiness clause is a declaratory provision showing the idea and principle which each and every constitutional right should pursue on its interpretation and enactment. ${ }^{46)}$ Korean Constitutional Court acknowledges pursuit of happiness as a comprehensive constitutional right and derives the general right to a free behavior and the right to free revelation of his/her personality from the pursuit of happiness clause. I think the due process clause should be used as a comprehensive and general clause deriving new constitutional rights rather than the pursuit of happiness clause in which the meaning of "happiness" is so vague and which we become hesitant to acknowledge as having a specific right considering the history and use of the clause in other countries. The U.S. derived substantive due process from the due process clause and fully used it as a comprehensive and general clause from which new constitutional rights originate. This fact enhances the possibility using due process clause in Korean Constitution as a comprehensive and general clause from which we could derive new constitutional rights.

Secondly, the fact that the procedural due process applies to the administrative process and controls this in a democratic way suggests many things to Korea. Although Korean Constitutional Court extended the application scope of due process to the administrative processes, the Court has not evidently developed the logic on what the contents of due process applying to the administrative processes are. Particularly, the fact that American procedural protection devices such as prior notice and evidentiary hearing could be supplied to the administrative processes through the procedural due process principle, and the fact that the offering scope of the procedural protection devices could be different depending on the balancing test

45) Art. 10 of Korean Constitution provides, "All citizens shall be assured of human dignity and worth and have the right to pursue happiness ..."

46) Jibong Lim, Korean Constitutional Court's decision on the marriage limitation between the ones with same surname and family origin [heonjae-ui dongseongdongbonkyeoljung-gwa haengbokchugujohang], 29-1 PUBLIC LAW Journal 123-142 (Korean Public Law Association, Dec. 2000). 
between the private interest of the people and the governmental interest really gives us good lessens who has not developed the concrete contents and criteria of procedural due process in this field.

\section{Conclusion}

The notion of due process produced 'procedural justice' in Anglo-saxon legal circle, and prevents us from falling into a pitfall that arrogance of the lawyers in Roman Civil law countries could easily fall into thinking 'Justice lies in the codes and lawyers perfectly know about it.' The fact that Korean Constitution in 1987 adopted due process clause implies in a sense that we reflected the dark history of misuse and overuse of law and suppression of human rights in the name of 'law' under military regimes for a quarter of a century until then. For this reason, due process clause in Korean Constitution is one of the most crucial constitutional provisions in terms of human rights protection. Its importance cannot be overemphasized. We should continuously focus on developing the theories and precedents on due process clause to make it a kernel provision for 'human rights protection' as it functions in the Anglo-saxon law countries including the United States.

KEY WORD: Due process, Art. 12 of Korean Constitution, Korean Constitutional Court 